\title{
Autonomy Principle and Fraud EXCEPTION IN DOCUMENTARY LETTERS OF Credit, a Comparative Study Between UNited STATES AND ENGLAND
}

\section{Hamed Alavi ${ }^{1}$ \\ Tallinn Law School, Tallinn University of Technology, Estonia email: Hamed.alavi@ttu.ee}

\begin{abstract}
ALAVI, Hamed. Autonomy Principle and Fraud Exception in Documentary Letters of Credit, a Comparative Study between United States and England. International and Comparative Law Review, 2015, vol. 15, no. 2, pp. 47-68.
\end{abstract}

DOI: 10.1515/iclr-2016-0035.

\begin{abstract}
Despite the fact that Documentary Letters of Credit are involved in process of International Trade for many centuries, but their legal personality is very new and their life span is much shorter than their existence. In the middle of Eightieth Century, Lord Mansfield introduced legal aspects of LC operation for the first time to the Common Law System. Later, International Chamber of Commerce started to codified regulations regarding international operation of Documentary Letters of Credit in 1933 under the title of Uniform Customs and Practices for Documentary Letters of Credit and updated them constantly up to current date. However, many aspects of LC operation including fraud are not codified under the UCP which subjects them to national laws. Diversified nature of National Laws in different countries can be source of confusion and problem for many businessmen active in international operation of Documentary Letters of Credit. Such differences are more problematic in Common Law countries as a result of following precedent. For Example, legal aspects of International LC transactions under British Law are only based on case law, however, American Law addresses Letter of Credit Operation under Article 5 of Unified Commercial Code. Due to important role of English and American law in practice of international trade, current paper will try to compare their approach to autonomy principle of in LC operation, fraud rule as a recognized exception to it and search for answer to following questions what is definition of fraud, and what are standards of proof for fraud in LC operation, under English and American law?
\end{abstract}

Keywords: Documentary Letters of Credit, Autonomy Principle, Fraud Rule, English Law, American Law, UCC.

1 Lecturer, Chair of Economic Law, Tallinn Law School, Tallinn University of Technology, Estonia; email Hamed.alavi@ttu.ee 


\section{Introduction}

Involvement in international trade has been always a temptation for businessmen. Although, doing business overseas has relatively high risks also providing higher level of profit in comparison with local market. Financial risks are well-known among other kinds of risk in international trade. Unlike doing trade in national markets, most of overseas traders have no information about the financial standing of other party and as result, it will be risky for exporter to part from goods before receiving payment and also importer will assume the risk of receiving non-conforming goods in case of making the payment before delivery of goods and checking. In the course of mercantile history, different methods of payment have been developed on the basis of market demand and goal of reducing financial risk for either party involved in international sales of goods. Among different existing methods of payment, Documentary Letters of Credit have a significant role in conduct of trade internationally by removing the outstanding risk of payment from a natural person (importer) and shifting it to the guarantee of legal person( a bank) for payment of purchased goods by importer against tender of complying documents by exporter. For many centuries Documentary Letters of Credit are in usage for the purpose of facilitating payments in international trade. However, their legal character has relatively short life span. Raymond Jack believes that entrance of Documentary Letters of Credit into the English legal system goes back to desire of Lord Mansfield in the middle of eighteenth century to include them in the Common Law practice ${ }^{2}$. Currently, relevant legal aspects of Documentary Letters of Credit are regulated via internationaly accepted Unified Customs and Practices for Documentary Letters of Credit which is prepared by International Chamber of Commerce. According to UCP, operation of documentary credits is subjected to two well recognized principles of independence which separates credit from its underlying contract and strict compliance which limits the responsibility of bank to honor the credit after tender of complying documents by beneficiary rather than being concerned about actual fulfilment of underlying contract. Despite warm welcome of trade society to UCP, still many legal aspects of Letter of Credit operation are regulated by national laws, including fraud and other exceptions to independence principle which are regulated by common law principles in England and Unified Commercial Code in United States of America. Current research will try to review the legal aspects of Principle of Autonomy in Documentary Letters of Credit while taking a comparative approach to fraud as the main exception to principle of autonomy in England and United States of America. Therefore, paper will try to find answers to questions regarding definitions, standards of proof, and legal remedies under English and American law.

2 Malek. A, Quest .D, Jack. Documentary credits: the law and practice of documentary credits including standby credits, and demand guarantees, Tottle, 2009 


\section{Principle of Autonomy}

Alongside with principle of strict compliance in operation of letters of credit and cornerstone of current article is Principle of Autonomy. Independence principle has been recognised and appreciated in national and international law ${ }^{3}$. The principle of autonomy of letters of credit has been considered as "the engine behind the letter of credit"4, and "cornerstone of the commercial validity of the letters of credit" 5 . Principle of Independence has been clearly mentioned in article 4 of UCP 600:

\section{"Article 4 Credits v. Contracts}

a. A credit by its nature is a separate transaction from the sale or other contract on which it may be based. Banks are in no way concerned with or bound by such contract, even if any reference whatsoever to it is included in the credit. Consequently, the undertaking of a bank to honour, to negotiate or to fulfil any other obligation under the credit is not subject to claims or defences by the applicant resulting from its relationships with the issuing bank or the beneficiary."

According to Article 4 of the UCP 600 and by referring to principle of independence, the beneficiary exporter receives the guarantee that he will be paid after tender the complying presentation of documents to the issuing bank. Neither bank nor the account party will be able to withhold payment with relevant arguments to the quality of delivered goods or other issues related to performance of underlying contract. Therefore, even in case of conflict on performance of underlying contract account party and issuing bank have no other choice rather than paying beneficiary upon presentation of complying documents and seek remedy by suing him for the breach of underlying contract. As a result, Autonomy Principle has been considered a means of promoting international trade by following the logic of "pay first, argue later"6

The autonomy principle also has been considered as the foundation for smooth operation of letter of credits by many scholars. ${ }^{7}$

In order to completely address the essence of autonomy principle, article 5 of UCP 600 specifies: "banks deal with documents and not with goods, services or performance to which the documents may relate."

3 Article 4 UCP 600; Article 2(b) URDG; Articles 2 and 3 UNCITRAL-Convention; sections 5-10 (1)(a), 5-114 (1) and 5 5-103(d) UCC

4 Arkins.J.R.C. (2000) "SNOW WHITE V. FROST WHITE: THE NEW COLD WAR IN BANKING LAW" Journal of International Banking Law, J.I.B.L. 2000, 15(2), 30-41

$5 \quad$ Ward Petroleum Corp. v Federal Deposit Ins. Corp. (1990) 903 F.2d 1299.

6 Dolan. J .F, (1996). The Law of Letters of Credit: Commercial and Standby Credits, Fourth Edition, Warren, Gorham \& Lamont, Incorporated, USA

7 Eakin v Continental Illinois National Bank \& Trust Co. (1989) 875 F.2d 114 .116.

$8 \quad$ UCP600. Article 5 


\subsection{Principle of Autonomy and Common Law Position}

The principle of autonomy has been recognized in many common law cases? Particularly, the importance of autonomy principle has been recognized by Lord Diplock in United City merchants (Investment) Ltd $v$ Royal Bank of Canada ${ }^{10}$.

'The whole commercial purpose for which the system of confirmed irrevocable documentary credits has been developed in international trade is to give to the seller an assured right to be paid before he parts with control of the goods that does not permit of any dispute with the buyer as to the performance of the contract of sale being used as a ground for non-payment or reduction or deferment of payment'

Trans Trust SPRL $v$ Danubian Co Ltd ${ }^{11}$ is other English case which raise the importance of autonomy principle when Denning LJ refers to necessity for seller to finaince his own suppliers and as a result relies on provided LC by buyer for honouring his own account payables to the third party.

Ameircan Case law also illustrates the importance of autonomy principle . For Example in Semetex Corporation v UBAF Arab American Bank ${ }^{12}$,US District court granted Semtex a summary Judgement against the UBAF on the basis of autonomy principle of Irrivocable Letters of Credit depsite the fact that underlying contract was not performed due to the Executive Order which blocked all Iraqi assets in USA after Iraqi invation to Kuwait on August 2, 1990. Power Curber International Ltd $v$. National Bank of Kuwait SAK ${ }^{13}$ is another case which prohibits applicatant and issuing bank from dishonoring the credit based on non performance of the underlying countract .

\subsubsection{Uniform Commercial Code of USA}

In United States of America, Documentary Letters of Credit are governed by Article 5 of Uniform Commerical Code . Unlike earlier version of Article 5 of UCC did not point at the autonomy principle ${ }^{14}$ revised vesion of UCC Article 5 clearly sepatrates the undertaking of issuer in documentary letter of credit from existance, non-existance, performance or non-perforance of underlying contract.

'the rights and obligations of an issuer to a beneficiary or a nominated person under a letter of credit are independent of the existence, performance, or non-performance of the contract or arrangement out of

9 Hamzeh Malas \& Sons v. British Imex Industries Ltd [1958] 2 QB 127; [1958] 2 WLR 100; [1958] 1 All ER 262, C.A.

10 United City Merchants (Investments) Ltd v Royal Bank Of Canada [1983] 1AC 168,183

11 Trans Trust SPRL v Danubian Co Ltd [1952] 2QB 297 at 304

12 [1995] 2Bank LR 73

13 [1981]2 Lloyd's Rep 394.

14 Enonchong, N. (2011). The independence principle of letters of credit and demand guarantees. Oxford University Press. 
which the letter of credit arises or which underlie it, including contracts or arrangements between the issuer and the applicant and between the applicant and the beneficiary ${ }^{15}$

'an issuer is not responsible for the performance, non-performance of the underlying contract, arrangement, or transaction ${ }^{16}$

\subsection{Exceptions to the Autonomy Principle}

The autonomy principle provides beneficiary with the guarantee of the bank for payment against any issue within of the terms of documentary Credits ${ }^{17}$. Such guarantee desires payment to the beneficiary regardless to any dispute on the underlying contract, upon tender of complying documents. Therefore, the autonomy principle creates a weaker position for account party against abusive demands of beneficiary and his fraudulent claims. On such occasions, relying on strict compliance principle and rejection of non-complying documents by bank will be the only defence of applicant. However, this defence might not work when the beneficiary is determined to obtain payment on the basis of presenting fraudulent Documents. On the other hand, the beneficiary has the upper hand against the issuing bank and account party in which regardless to any dispute on the contract of sales, he is entitled for payment upon tender of complying documents. Such upper hand can be an incentive for abusive demand for payment or presentation of fraudulent documents by beneficiary. For a long period of time the general belief was supportive towards the absolute nature of independent principle ${ }^{18}$. However, it became clear that exceptions are needed to deal with abusive and fraudulent demands. As result, the fraud exception has been established which is recognized by all common law and many civil law countries. In cases of fraud, court has the obligation to decide between respecting the principle of autonomy and grating injunction to stop payment after considering public policy, statutes, public interest and third party rights ${ }^{19}$. Despite the fact that Fraud rule is a recognized expectation to principle of autonomy of documentary credits, but there is no standard ${ }^{20}$ regarding time and circumstances in which it should supersede the autonomy principle ${ }^{21}$. Later it become clear that exercising the public interest requires application of exceptions in case of illegal underlying

15 UCC. Article 5-103(d)

16 UCC. Article 5-108(f)(1)

17 Enonchong, N. (2011). The independence principle of letters of credit and demand guarantees. Oxford University Press 93

18 United City Cooperation v. Allied Arab Bank (1985) 2 Lloyds Rep .554,561

19 Garcia RLF 'Autonomy principle of the letter of credit' (2009) Mexican Law Review 69

20 Gao X 'The Fraud Rule in the Law of Letters of Credit: A Comparative Study' (2002) is the most comprehensive study as regards the issue of the fraud rule;

21 Gao X., \& Buckley, R. P. (2003). Comparative Analysis of the Standard of Fraud Required under the Fraud Rule in Letter of Credit Law, A. Duke J. Comp. \& Int'l L., 13, 293. 
contract $^{22}$. Therefore, clear evidences show that English Legal system is ready to recognize other exceptions to the principle of autonomy.

\section{Fraud Exception}

In fact, Fraud is very old and well-known phenomenon in the business world. "As long as there have been commercial systems in place there have been those who have tried to manipulate these systems." 23 Fraud has been considered as the "the most controversial and confused area" 24 as it "goes to the very heart" of the letter of credit by providing the bank to look at the facts behind complying presentation of beneficiary and stop payment in cases of fraud in transaction. ${ }^{25}$.

\subsection{The meaning of Fraud}

According to the Article 5 of UCP 600, "bank deals with documents not goods or services" 26 which means that "banks deal in written presentations not facts" 27 .

Therefore, beneficiary does not have to prove fulfilment of his obligations in underlying contract and only presentation of complying documents will entitle him to receive payment from issuing bank. As a result, strict implementation of autonomy principle will create three distinctive scenarios regarding presentation of documents by beneficiary.

First, beneficiary presents complying documents and performs his obligations under the sales contract with account party. As a result, bank will allow payment after checking documents.

Second, beneficiary presents non-complying documents while performing his obligations under the contract of sales with account party. In such situation, bank may or may not authorize payment to the beneficiary (bank may ask for waiver from account party or corrections from beneficiary).

Third scenario takes place when beneficiary presents complying documents to the terms of credit but does not perform his obligations under sales contract with account party. In such occasion, strict application of autonomy principle might lead us to fraud by beneficiary and injustice towards account party who has to bear the loss as the last person in the chain of transaction.

22 Enonchong N 'The Autonomy Principle of Letters of Credit: An Illegality Exception?' (2006) Lloyd's Maritime and Commercial Law Quarterly 404

23 Trade Finance Fraud -Understanding the Threats and reducing the Risk, A Special Report prepared by the ICC International Maritime Bureau (Paris) 2002, p. 9

24 Buckley RP \& Gao X (2002),p. 663 referring to Anon "'Fraud in the Transaction": Enjoining Letters of Credit during the Iranian Revolution' 93 (1980) Harvard Law Review. P.92

25 Gao X \& Buckley RP (2003), p. 293

26 UCP600, Article 5

27 Harfield.H, Bank Credits and Acceptances (5th ed., 1974) New York, p. 69 
In such occasions and in order to prevent fraud, the law of letters of credit has created fraud exception to the autonomy principle of letters of credit. However, fraud expiations has been approached by different scholars and national laws in different ways .UCP 600 as the most popular set of applicable rules to documentary letters of credit take an absolute silent position towards fraud rule while leaving it open to the relevant municipal law which show a drastically non harmonious approach to the subject matter. Even the provided definitions for fraud rule are not harmonious. Gao Xiang considers fraud exception in documentary credits as "an extraordinary rule as it represents a departure from the cardinal principle of the law of letters of credits - the principle of independence. It allows the issuer or a court to view the facts behind the face of conforming documents and to disrupt the payment of a letter of credit when fraud is seen to be involved in the transaction" 28 . Schmitthoff mentions that fraud rule "permits a court to consider evidence other than the actual terms and conditions of the credit and is founded on the maxim ex turpi causanonoritur actio" 29 . Conveying the message that fraudulent beneficiary will not be able to find an action based on his wrongdoing. Raymond Jack refers to fraud rule as "exception to the rule that the contracts made in connection with credits are autonomous" 30

\subsection{Rational for the Fraud Rule}

Gao has defined three rational for establishment and enforcement of fraud rule $^{31}$ :

1. Closing the loophole in law: Strict application of autonomy principle and providing absolute guarantee for payment to beneficiary upon presentment of complying documents might provide an opportunity for perpetrators of fraud to harm the system of international trade and operation of documentary credits by presenting forged or fraudulent documents to the bank which comply on their face with terms of credit, but do not perform their obligations under the contract of sales with account party ${ }^{32}$. There are doubts about capability of fraud rule to prevent any injustice resulted from fraud, but definitely it will reduce the loophole which has been created by the autonomy principle. ${ }^{33}$

2. Public Policy: The second rational for fraud exception is the result of public policy's concern over controlling and defying fraud. There should not be a possibility for fraudster beneficiary to benefit from autonomy

28 Gao X, The fraud rule in the law of Letters of Credit (2002) The Hague, p. 30

29 Schmitthoff's Export Trade - The Law and Practice of International Trade (12th ed., 2012) Sweet \& Maxwell , p. 210

30 Malek. A, Quest.D, Jack. Documentary credits: the law and practice of documentary credits including standby credits, and demand guarantees, Tottle, 2009

31 Gao X (2002) 29 and 98

32 Ibid 30

33 Ibid 
principle while trying to obtain payment by presentation of forged documents. ${ }^{34}$ The interest of public policy in prevention of fraud has been reflected in many authorities. Also in United City Merchants (Investment) Limited $v$ Royal Bank of Canada ${ }^{35}$, Lord Diplock comments on ex turbi causa non oritur ${ }^{36}$, intention of court not to allow its process to be used by dishonest person to carry out the fraud as basis for the fraud rule.

3. To Maintain the Commercial Utility of Letters of Credit. Documentary letters of credit act towards balancing the contradictory interests of beneficiary and applicant. Tendered documents including the bill of lading not only play a significant role in operation of the Letters of Credits but also provide security for the bank before being reimbursed by account party. Therefore, bank's security interest will be abused in case of beneficiary's fraud. As a result the balance in the operational scheme of documentary letters of credit will be undermined while neither of users will have faith in commercial utility of documentary letters of credit anymore ${ }^{37}$.

In response to critics of Fraud Rule who argue about capability of issuing bank and account party to take legal action against beneficiary based on the breach of the underlying contract, supporters of application of fraud rule consider such legal action as a valuable alternative because, fraudulent beneficiary "absconds before the fraud or forgery is discovered"

\subsubsection{Sztejn v Henry Schroder Banking Corporation}

The American case of Sztejn $v$ Henry Schroder Banking Corporation ${ }^{39}$ had a significant role in development of the Fraud rule in documentary letters of credits $^{40}$. Sztejn is considered landmark cases as it has been used in codification of the 1962 version of UCC as well as being basis for judgment in following cases of fraud in documentary credits inside and outside United States of America ${ }^{41}$. According to Gao, "It shaped the fraud rule in "virtually all jurisdictions" ${ }^{42}$

34 Ibid

35 United City Merchants (Investment) Limited $v$ Royal Bank of Canada [1982] 2 All E.R. 725

36 Ex turpi causa non-oritur actio can be translated as 'no action can be based on a disreputable cause', Law J \& Martin EA 'A Dictionary of Law' 7 ed (2009)

37 Buckley RP \& Gao X (2003) Buckley .RP \& GAO. X, 'The Development of the Fraud Rule in Letter of Credit Law: The Journey so Far and the Road Ahead' (2003) 23 U Pa J of Int'l L ,667

38 Ellinger P 'Documentary Credits and Fraudulent Documents' in Chinkin CM, Davidson RJ et al.eds. 'Current Problems of International Trade Financing' (1983) 191

39 Sztejn $v$ Henry Schroder Banking Corporation 31 NYS 2d 631 (1941)

40 Buckley RP \& Gao X (2003) 676

41 In 1964 version of UUC fraud rule was under Article 5 section 5-114 but after revision of 1995 it is under Article 5, section 5-109.

42 Kelly-Louw, M. (2009). The documentary nature of demand guarantees and the doctrine of strict compliance (part 1). SA Mercantile Law Journal= SA Tydskrif vir Handelsreg, 21(3), 306-321 
In case of Sztejn, underlying contract of sale was between Sztejn (buyer) and Transea Traders Ltd (seller). The payment was due under the letter of credit issued by Schroder by drawing a draft to the Chartered Bank (presenting bank). Sztejn asked for injunction before presentation of documents for payment on the basis of dispatching "cow hair, other worthless material and rubbish with intent to simulate genuine merchandise and defraud the plaintiff"43. Sztenjn also mentioned Chartered bank as colleting bank for Transea Trades not the holder in due course for the draft. However, Chartered Bank defended that the presenting banks "is only concerned with the documents and on their face these conform to the requirements of the letter of credit" ${ }^{34}$. In the course of hearing, all allegations of cases were considered as true by Justice Shientag who rejected the motion to dismiss the complaint of plaintiff by Chartered Bank based on two arguments: allegation that fraud has been commented and established fact that fraud has been committed in the underlying transaction. However, in continuation, he pointed at necessity for overruling the principle of autonomy in case of fraud:

„Of course, the application of this doctrine [the principle of independence] presupposes that the documents accompanying the draft are genuine and conform in terms to the requirements of the letter of credit." ${ }^{35}$

The Justice Sheintag held that motion of Chartered Bank for dismissing complaint of plaintiff is dismissed as well as injunction was granted to the Sztejn on the basis that :

„Transea was engaged in a scheme to defraud the plaintiff... that the merchandise shipped by Transea is worthless rubbish and that Chartered Bank is not an innocent holder of the draft for value but is merely attempting to procure payment of the draft for Transea's account ${ }^{\star 46}$.

Apart from the beneficiary's fraud, two other issues where discussed in the hearing ${ }^{47}$ :

First was bank's security interest as one of the supporting reasons behind application of fraud rule. The Justice Shientag mentioned:

"While the primary factor in the issuance of the letter of credit is. The credit standing of the buyer, the security afforded by the merchandise is also taken into account".48

Second issue was exemption of the holder in due course from being subjected to the application of fraud rule.

43 Sztejn v Henry Schroder Banking Corporation 31 NYS 2d 631 (1941) 633

44 ibid, 632.

45 Ibid 633

46 Ibid

47 Lu, Lu. "The Exceptions in Documentary Credits in English Law." (2011). 75

48 Sztejn v Henry Schroder Banking Corporation 31 NYS 2d 631 (1941), 634-635 
"On this motion only the complaint is before me and I am bound by its allegation that the Chartered Bank is not a holder in due course but is a mere agent for collection for the account of the seller charged with fraud. Therefore, the Chartered Bank's motion to dismiss the complaint must be denied, if it had appeared from the face of the complaint that the bank presenting the draft for payment was a holder in due course, its claim against the bank issuing the letter of credit would not be defeated even though the primary transaction was tainted with fraud. "“9

Therefore, decision of Sztejn established the basic principles of the Fraud Rule which can be listed as below: ${ }^{50}$

1. The payment process and autonomy principle of the letters of credit can be superseded only in case of fraud. However, the fraud should be established and only allegations of fraud will not suffice for interruption of payment.

2. The payment to the holder of due course or presenter with similar status will not be interrupted even in case of established fraud.

However, it should not be forgotten that in cases of Sztejn all allegations were considered as fact and as a result issue of the standard of proof for fraud was left open to be one the most controversial issues in application of fraud rule in documentary letters of credits. ${ }^{51}$ Therefore, it is possible to conclude that "Shientag J was only making decision for Sztejn case where the fraud had been already proved from the beneficiary side and there was doubt about it"52.

\subsection{Application of Fraud Exception}

In this section, focus will be on application of fraud rule in documentary credits in different Common Law Jurisdictions. Namely, United States of America and England. Although many legal problems have the same symptoms wherever they occur, but their consequences and approaches to solve them can be drastically different from jurisdiction to jurisdiction. ${ }^{53}$. In such situation, comparative study of legal problems like fraud rule in documentary letters of credit can be a good approach to find similarities and differences among common law jurisdictions and try to harmonize them. Although, English Law is strongly influenced by developments of American Law in field of documentary credit's fraud, but comparative studies which have been done in this area show the significant devi-

49 Ibid

50 Gao X (2002) 42

51 Ibid

52 Lu, Lu. "The Exceptions in Documentary Credits in English Law." (2011).76

53 Gordley J (1995) 'Comparative Legal Research: Its Function in the Development of Harmonized Law' (1995) 43 American Journal of Comparative Law 560 
ations in application of fraud rule between United States of American, England and other common law countries ${ }^{54}$.

\subsubsection{Fraud Rule in American Law}

Development of fraud rule in United States of American law can be categorized under three main time periods: Pre-UCC, The previous UCC Article 5 and Revised UCC Article $5^{55}$.

The period of pre UCC was governed by the case law and it was mostly influenced by the case of Sztejn as it has been discussed in previous section.

\section{Revised UCC Article 5}

In 1995 the UCC article 5 went through revision mostly to overcome existing weaknesses, gaps and errors of the original statute as well as challenges which were the result of constant development of letters of credits ${ }^{56}$. After revision, fraud rule was embodied in UCC article 5 sub - sections $109^{57}$

By coming into effect of revised UCC article 5 fraud rule went through a significant changes and received moderation from different aspects including ${ }^{58}$ :

1. According to Article 5-109, discovery of fraud will disrupt the normal process of documentary letter of credit. Refusing to honour the credit at presentation by issuing bank ${ }^{59}$, and request of account party from court to grant injunction in order to prohibit payment. ${ }^{60}$

2. Article 5-109 provides guidance for two of the most controversial aspects in fraud rule. Firstly, it sets the standard of proof as materiality of fraud and also it provides that fraud exception covers fraud in documents as well as underlying contract. ${ }^{61}$

3. In section 5-109 (1) four groups of people are considered immune against application of the fraud rule. "A) Nominated person with good faith who has paid without notice of fraud. B) Confirmer who has honoured its confirmation in good faith C) The holder in due course of the

54 Kelly-Louw, M. (2009). The documentary nature of demand guarantees and the doctrine of strict compliance (part 1). SA Mercantile Law Journal= SA Tydskrif vir Handelsreg, 21(3), 306-321

55 Gao X \& Buckley RP (2003) 294

56 Gao Xiang (2002) 45

57 UCC article $5 \mathrm{sub}$ - sections 109

58 Buckley RP \& Gao X (2002) 686

59 UCC .Section 5-109(a)(2)

60 Section 5-109(b); Gao X (2002) 46

61 Kelly-Louw, M. (2009). The documentary nature of demand guarantees and the doctrine of strict compliance (part 1). SA Mercantile Law Journal= SA Tydskrif vir Handelsreg, 21(3), 306-321 
draft drawn under the letter of credit which was taken after acceptance by the issuer or nominated parson $\mathrm{D}$ ) an assignee of the issuer or nominated person's deferred obligation that was taken for value and without notice of forgery or material fraud after the obligation was incurred by the issuer or nominated person"62. Therefore, all four groups of protected people against fraud rule under revised article 5-109 are relevant unlike three groups of protected people under article 5-114 in which only one group was protected. ${ }^{63}$

4. The article 5-109 (b) defines four preconditions for court in order to award injunction. "Revised UCC Article 5, Section 5-109 now stands as the most comprehensive code of the fraud rule in the law of letter of credits in the common law world" ${ }^{\prime 4}$.

\subsubsection{The Fraud Rule in English Law}

Fraud rule is governed under the common law in England. Therefore, it has been recognized and considered in British cases ${ }^{65}$ Despite such recognition, traditionally English courts show reluctance in application of fraud rule and take a strict approach towards intervention with autonomy principle. In study of Fraud Rule in English Law, we will review some of the leading cases in this area as well as analysing scope of the application fraud rule under English law.

\section{Hamzeh Malas and Sons v British Imex Industries Ltd}

The case of Hamzeh Malas and Sons $v$ British Imex Industries Ltd ${ }^{66}$, is a good example for showing the strict historical approach of the English Courts on intervening in autonomy principle of documentary credits. The case is about buyers who signed a contract of sales for Steel Rods with the defendant seller. Payment was due by two confirmed letters of credits. After making the first payment, plaintiff buyer asked for injunction relief against the beneficiary on the basis of defectives of the first instalment ${ }^{67}$

While rejecting to award injunction in the court of appeal, Jenkins LJ commented on the autonomy principle:

"An elaborate commercial system has been built up on the footing that bankers' confirmed credits are of that character, and, in my judgment, it would be wrong for this court in the present case to interfere with that established practice [...] That system [...] would break down completely if

62 section 5-109(a)(1)

63 Buckley RP \& Gao X (2002) 687

64 Kelly-Louw, M. (2009). The documentary nature of demand guarantees and the doctrine of strict compliance (part 1). SA Mercantile Law Journal= SA Tydskrif vir Handelsreg, 21(3), 306-321

65 Buckley RP \& Gao X (2002),687

66 Hamzeh Malas and Sons v British Imex Industries Ltd [1958] 2 QB

67 Ibid 
a dispute as between the vendor and the purchaser was to have the effect of "freezing," if I may use that expression, the sum in respect of which the letter of credit was opened"68

\section{Harbottle (RD) (Mercantile) Ltd v National Westminster Bank Ltd}

In the case of Harbottle (RD) (Mercantile) Ltd $v$ National Westminster Bank $L t d^{69}$, Judge Ker reemphasized in the strict approach towards autonomy principle for another time:

"It is only in exceptional cases that the courts will interfere with the machinery of irrevocable obligations assumed by banks. They are the lifeblood of international commerce. Such obligations are regarded as collateral to the underlying rights and obligations between the merchants at either end of the banking chain. Except possibly in clear cases of fraud of which the banks have notice, the courts will leave the merchants to settle their disputes under the contracts by litigation or arbitration as available to them or stipulated in the contracts [...] Otherwise, trust in international commerce could be irreparably damaged" ${ }^{\prime 0}$

\section{Edward Owen Engineering Ltd $v$ Barclays Bank International Ltd}

The case of Edward Owen Engineering Ltd $v$ Barclays Bank International Ltd ${ }^{71}$ is one of the most frequently cited on principle of autonomy in English law. An English supplier in 1976 contracted the sale of greenhouse and their insulations with a Libyan party, Agricultural Development Council of Libya. According to the contract of sales, payment was supposed to be made in the format of an irrevocable documentary credit in favour of the plaintiff at local Libyan bank (Umma Bank). In return, the defendant bank (Barclays) issued a demand guarantee without proof or condition upon the advice of the plaintiff which was sent to the customer. However, the letter of credit opened in favour of seller by Libyan bank was not confirmed. As a result of failing to convince the Libyan party to confirm the letter of credit, plaintiff repudiated the contract of sales. Libyan party raised claims for demand guarantee.

“... The performance guarantee stands on a similar footing to a letter of credit. A bank which gives a performance guarantee must honour that guarantee to its terms. It is not concerned in the least with the relations between the supplier and the customer; nor with the question whether the supplier has performed his contracted obligations or not; nor with the question whether the supplier is in default or not. The bank must pay according to its guarantee, on demand, if so stipulated, without proof or

68 Ibid

69 Harbottle (RD) (Mercantile) Ltd v National Westminster Bank Ltd [1978] 1 QB 146.

70 Ibid

71 Edward Owen Engineering Ltd v Barclays Bank International Ltd. [1978] 1 Lloyd's Rep. 166 
condition. The only exception is when there is a clear fraud of which the bank has notice."72

\section{Discount Records Ltd. v. Barclays Bank Ltd}

The case of Discount Records Ltd. v. Barclays Bank Ltd ${ }^{73}$ can be considered the first English case which cited and approved Sztejn ${ }^{74}$. The contract of sales was signed between English buyer and French seller for the purchase of gramophone records and cassettes. According to the sales contract, buyer applied to Barclays bank for a letter of credit in favour of the seller. After shipment of goods by seller, he tendered the draft and other documents to the confirming bank in Paris and received the payment. However, in presence of the bank's representative, buyer found goods as non-complying and rubbish. As a result, he applied for injunction against honouring presentation by the issuing bank by referring to the case of Sztejn while claiming that seller has perpetrated fraud ${ }^{75}$. In the course of hearing, Judge Megarry considered the case different from Sztejn and rejected injunction against bank. According to the Megarry J, fraud was established in cases of Sztejn while in present case, there was mere allegation of fraud ${ }^{76}$ "because it is unlikely that any action to which the seller was not a party would contain the evidence reuired resolving this issue" 77

In the decision of Discount Records Ltd. v. Barclays Bank Ltd it was also held that bank's payment has no effect on the buyer's interest as buyer has possibility to claim damages from bank in case of bank's wrong payment to seller ${ }^{78}$ Such approach complies with common law practice that court will only issue injunction at the time that it is the final solution and applicant has no other legal resources. ${ }^{79}$

\section{United City Merchants (Investmen t) Limited $v$ Royal Bank of Canada}

The case of United City Merchants (Investment)Limited $v$ Royal Bank of Can$a d a^{80}$ is one of the most important and well-known English cases of fraud rule in documentary credits. ${ }^{81}$

72 Ibid, 171-172

73 Discount Records Ltd. v Barclays Bank Ltd [1975] 1 Llyod's Law Reports 444

74 Zhang, Y. Approaches to Resolving the International Documentary Letters of Credit Fraud Issue. University of Eastern Finland, 2011.80

75 Discount Records Ltd v Barclays Bank Ltd [1975] 1 Llyod's Law Reports 444-446

76 Ibid 447

77 ibid

78 Zhang. Y,( 2011) 81

79 Tóth, Z. "DOCUMENTARY CREDITS IN INTERNATIONAL COMMERCIAL TRANSACTIONS WITH SPECIAL FOCUS ON THE FRAUD RULE., 2006, 102

80 United City Merchants (Investment) Limited v Royal Bank of Canada [1979] 1 Lloyd's Law Reports 267

81 Ibid 


\section{The Facts:}

The contract of sales was established between Peruvian buyer Vitrorefuerzos SA (Vitro) and Glass Fibres, English seller on December 1975. According to the contract the method of Payment was to be irrevocable, transferable letter of credit. The credit was opened by Peruvian bank Banco Continental SA and received confirmation by Royal Bank of Canada. The seller on $2^{\text {nd }}$ December 1976 informed the freight forwarding agent about necessity to ship goods latest on $15^{\text {th }}$ December. However, as the result of the cancelation of original vessel, goods were replaced in another vessel (American Accord) and shipped on 16 of December 1976. The bill of lading was made out by Mr. Backer the employee of the carrier on the date of shipment. The agent changed the date on the face of bill to 15 of December 1976. Bill of lading also mentioned the port of departure as London while in fact goods were shipped from Felixstowe. ${ }^{82}$ Credit was dishonoured after presentation of documents by United City Merchants, assignee of the seller to the bank on the basis that commercial invoice did not comply with terms of credit and also banks information about forged nature of the bill of lading ${ }^{83}$. Plaintiff initiated a legal action against defendant based on wrongful dishonouring of the credit and claiming about their lack of knowledge about incorrect date of the face of bill of lading. In the trial court Justice Mocatta ruled for beneficiary ${ }^{84}$. In the court of appeal, judgement was changed in favour of the bank by taking the concept of "Half Way House" which was explained as "between fraud and accuracy namely in inaccuracy in material particular" ${ }^{85}$ In the House of Lords, Lord Diplock was delivering the leading speech . He started with describing the nature of autonomous contracts in the framework of the letter of credit's operation while emphasizing the dispute in the goods are not relevant to the right of seller for payment. ${ }^{86}$

"To this general statement of principle [of independence] [...] there is one established exception: that is, where the seller, for the purpose of drawing on the credit, fraudulently presents to the confirming bank documents that contain, expressly or by implication, material representations of fact that to his knowledge are untrue. Although there does not appear among the English authorities any case in which this exception has been applied, it is well established in them American cases of which the leading or "landmark" case is Sztejn v. J. Henry Schroder Banking Corporation. [...] The exception for fraud on the part of the beneficiary seeking to avail himself of the credit is a clear application of the maxim ex turpi causa

82 Ibid

83 Ibid

84 Ibid

85 Malek A \& Quest D 'Documentary Credits - The Law and Practice of Documentary Credits Including Standby Credits and Demand Guarantees' (2009) , 264

86 United City Merchants (Investment) Limited $v$ Royal Bank of Canada [1979] 1 Lloyd's Law Reports 
non oritur actio or, if plain English is to be preferred, "fraud unravels all." The courts will not allow their process to be used by a dishonest person to carry out a fraud" 87

Since seller had no information about fraudulent act of Mr. Baker in manipulating the true date of shipment on face of the bill of lading and their honest belief in "that it was true and the goods had actually been loaded on or before the 15 th of December 1976, as required by the documentary credit" 88 the beneficiaries held innocent and as the final judgment, the House of Lords ruled that: "the instant case ... does not fall within the fraud exception" 89

United Trading Corporation SA and Murray Clayton Ltd $v$ allied Arab Bank Ltd

The case of United Trading Corporation SA and Murray Clayton Ltd $v$ Allied Arab Bank $L t d^{90}$ introduced the test of "only realistic Inference". The test of only realistic inference received acceptance by deferent judges as a standard of establishing fraud ${ }^{91}$ In the United Trading Corporation SA and Murray Clayton Ltd $v$ allied Arab Bank Ltd, Justice Ackner defined the standard of evidence as:

The evidence of fraud must be clear, both as to the fact of fraud and as to the bank's knowledge. The mere assertion or allegation of fraud would not be sufficient. [...] We would expect the Court to require strong corroborative evidence of the allegation, usually in the form of contemporary documents, particularly those emanating from the buyer." ${ }^{22}$

\subsection{English position on the Fraud Rule in Documentary Letters of Credits:}

Overall observation shows the English courts have restrict and narrow approach towards intervention in autonomy principle of letters of credit. In general scope for the fraud rule under English legal system can be summarised as: ${ }^{93}$

Material representation of the fact that is untrue, Knowledge of the beneficiary, Documentary Fraud versus Fraud in the Underlying contract

87 Ibid, 301

88 Ibid, 302

89 Ibid, 303

90 United Trading Corporation SA and Murray Clayton Ltd v Allied Arab Bank Ltd [1985] 2 Lloyd's Law Reports 554 (CA)

91 Kelly-Louw, M. (2009). The documentary nature of demand guarantees and the doctrine of strict compliance (part 1). SA Mercantile Law Journal= SA Tydskrif vir Handelsreg, 21(3), 306-321

92 United Trading Corporation SA and Murray Clayton Ltd v Allied Arab Bank Ltd [1985] 2 Lloyd's Law Reports 554, 561

93 Ellinger .P, Noe. D, The Law and Practice of Documentary Letters of Credit , (2010) , 141 


\subsubsection{Material representation of the fact that is untrue}

In the case of United Trading Corporation SA and Murray Clayton Ltd $v$ Allied Arab Bank Ltd, Lord Diplock comments on material misrepresentation when considering the third party fraud.

"To this general statement of principle [of independence] as to the contractual obligations of the confirming bank to the seller, there is one exception: that is, where the seller, for the purpose of drawing on the credit, fraudulently presents to the confirming bank documents that contain, expressly or by implication, material representations of fact that to his knowledge are untrue"94.

Accordingly, material misrepresentation to Lord Diplock is a sort of fraud which can invoke the fraud rule under English Law. ${ }^{95}$ In an interpretation close to interpretation of the material fraud in official comment on Revised UCC article 5-109, Jack states on meaning of the word Material:

"Material to the bank's duty to pay, so that if the document stated the truth the bank would be obliged to reject the documents,"

However, interpretation of Jack does not match with the interpretation of Lord Diplock:

"[T]he answers to the question: "to what must the misstatement in the documents be material?" should be: "material to the price which the goods to which the documents relate would fetch on sale if, failing reimbursement by the buyer, the bank should be driven to realise its security.97

It has been suggested that, Lord Diplock's interpretation on material misrepresentation goes back the value of goods. Therefore, in his view predating the bill of lading will not constitute misrepresentation as it has no effect on value of goods $^{98}$. However, Jack's interpretation considers the effect of presentation on duty of bank to pay as material. As a result, statement of true date of shipment in case of predated bill of lading will result in rejection of document by bank ${ }^{99}$. It has been submitted that Jack's interpretation is much stronger argument than interpretation of Lord Diplock.

Material Misrepresentation has been considered as the standard of proof for fraud in documentary credits under English Law and it has been accepted in

94 (1983) 1 A.C. 168,183

95 Buckley RP \& Gao X (2003) , 324

96 Malek A \& Quest D 'Documentary Credits - The Law and Practice of Documentary Credits Including Standby Credits and Demand Guarantees' (2009) , 254

97 (1983) 1 A.C, P.118

98 Buckley RP \& Gao X (2003) , 324

99 Ibid 
subsequent cases like Themehelp Ltd. v. West ${ }^{100}$ and Banco Santander S.A. v. Bayfern $\operatorname{Ltd}^{101}$.

\subsubsection{Knowledge of the beneficiary}

According to the United City Merchants, beneficiary was not held responsible formisrepresentation of documents and in fact he was not aware of them ${ }^{102}$. Therefore, it can be interpreted from Lord Diplock's approach that preventing beneficiary from claiming payment will not only include the situation that he was responsible for the fraud, but also at the time of presentation, he should be aware of misrepresentation in tendered documents even if he is not responsible for them. ${ }^{103}$

In this respect, degree of beneficiary's knowledge of fraud before being infected by fraud exception can be a concerning problem ${ }^{104}$. "This is likely to require actual knowledge rather than constructive knowledge based on what the beneficiary as a reasonable man should have known. The question of what constitutes actual knowledge should be approached cautiously: a wilful shutting of one's eyes to the truth may in practice lead a court to make a factual finding that the beneficiary did know of the falsity." 105

\subsubsection{Documentary Fraud versus Fraud in the Underlying Transaction.}

Despite the fact that Lord Diplock in United City Merchants emphasized that fraud should be relevant to documents, it is not possible to comprehend whether his lordship raised the issue of documentary fraud only due to the facts of the current case or he wanted it to the requirement for all relevant cases to fraud in documentary credits. Later English cases do not show strong adherence to this issue. ${ }^{106}$ For example, in Czarnikow-Rionda Sugar Trading Inc $v$ Standard Bank London $^{107}$, in Court of Appeal, Rix J discharged the obtained interim injunction by buyer to prevent issuing bank from honouring the presentation based on issues other than fraud allegation not being based on documents.

Scholars argue that as fraud Rule follows the rational of preventing fraudulent beneficiary from benefiting from his own wrong, there is a merit of extending the exception to underlying transaction. However, it must be clearly established that fraud is in connection with credit transaction like fraudulent demand of beneficiary under the credit. ${ }^{108}$ The position of other Common law Jurisdic-

100 ThemehelpLtd. v. West, (1995) 4 All E.R. 215

101 Banco Santander S.A. v. Bayfern Ltd, 1999 WL 250019 (Q.B. June 9, 1999), aff'd, 2000 WL 191098 (C.A. Feb. 25, 2000)

102 Ellinger .P, Noe. D, The Law and Practice of Documentary Letters of Credit , (2010) , 142

103 Ibid

104 Ibid

105 Ibid

106 Ibid

107 Czarnikow-Rionda Sugar Trading Inc v Standard Bank London (1996) 1WRL 1152, 1161

108 Ellinger .P, Noe. D , The Law and Practice of Documentary Letters of Credit , (2010) , 143

(c) Palacký University Olomouc, Czech Republic, 2015.

ISSN 1213-8770 (print), ISSN: 2464-6601 (online). 
tions show extension of Fraud Rule to the underlying contract. In United States of America, Revised UCC Article 5-109 extends the fraud rule to documents as well and underlying contract. ${ }^{109}$

"Requires that the fraudulent aspect of a document be material to a purchaser of that document or that the fraudulent act be significant to the participants in the underlying transaction."110

In Canada, Le Dain J from Supreme Court of Canada in case of Bank of Nova Scotia v. Angelica-Whitewear Ltd ${ }^{111}$ extended the application of fraud rule to the underlying contract.

In contrast, Singaporean courts have taken a narrow approach to the application of fraud rule by limiting it only to fraud in documents. The court of Appeal of Signature In the case of White and Co Inc vs Chamet Handel Training (S) Pte $L t d^{12}$ emphasized that fraud sufficient for constituting the exception to the autonomy of irrevocable documentary letters of credit was fraud in presentation of required documents to the bank while obligations of issuing or confirming banks towards the beneficiary will not be affected by the fraud in underlying contract. ${ }^{13}$

\section{Conclusion}

Reason de Etre of the documentary letters of credit can be mentioned as the need of market to an instrument of payment in international business which can mitigate the commercial risk between buyer and seller who do not have any information from financial capacity of each other. As a result, we can witness the development of documentary letters of credits in the course of history as an improvised act of market which has been regulated by customs and usages of the same market. According to UCP, operation of Documentary Letters of Credits is subjected to two main principles of autonomy and strict compliance. While principle of Autonomy tries to protect rights of seller by separating the underlying contract of sales from credit and by requiring buyer to pay first and argue later in case of any problems in fulfilment of underlying contract, the principle of strict compliance protects rights of buyer by requiring seller to provide genuine documents which comply with terms of credit. Interestingly, among common law countries only USA has naturally applicable statute for operation of documentary letter of credits while other countries including England follow the case law system.

109 Buckley RP \& Gao X (2003)317

110 Official Comment to Article 5 of the Uniform Commercial Code, para. 2.

111 Angelica-Whitewear Ltd v Bank of Nova Scotia 36 D.L.R. (4th) 161, EYB 1987-67726

112 White and Co Inc vs Chamet Handel Training (S) Pte Ltd(1993) 1 SLR 65

113 Ibid 
There is still long way to be taken by common law courts ,particularity English Judges should show a harmonized approach to problem of fraud and other exceptions to the principle of autonomy of documentary letters of credit. Current research took a critical view to such divergent approach of English courts to the relevant issues to fraud rule and compared it with American approach to the same problem based on Article 5 of the Unified Commercial Code. In the course of study, efforts were made to analyse reasons behind historical reluctance of English courts towards intervention into the operation of autonomy principle, absence of harmonized standard of proof for fraud, difficulties in obtaining interim relief from the court and non-recognition of other exceptions. The outcomes of study in this field are of the high importance as existing problems of fraud as the main exception to principle of autonomy may have negative effect on the perception of businessmen at global level on capability of Documentary Letters of Credit in mitigating the commercial risk of international trade.

\section{References}

Angelica-Whitewear Ltd v Bank of Nova Scotia 36 D.L.R. (4th) 161, EYB 198767726

ARKINS, JR. "Snow White v. Frost White: The New Cold War in Banking Law?." JOURNAL OF INTERNATIONAL BANKING LAW 15, no. 2 (2000): 30-41

Banco Santander S.A. v. Bayfern Ltd, 1999 WL 250019 (Q.B. June 9, 1999), aff'd, 2000 WL 191098 (C.A. Feb. 25, 2000)

Buckley, Ross P., and Xiang Gao. "Development of the Fraud Rule in Letter of Credit Law: The Journey So Far and the Road Ahead." U. Pa. J. Int'l Econ. L. 23 (2002): 663.

Code, Uniform Commercial. “Uniform Commercial Code." Uniform Laws (2001). Czarnikow-Rionda Sugar Trading Inc v Standard Bank London (1996) 1WRL 1152,1161

Discount Records Ltd v Barclays Bank Ltd [1975] 1 Llyod's Law Reports 444-446 Dolan, J,F, The Law of Letters of Credit: Commercial and Standby Credits, Fourth Edition, Warren, Gorham \& Lamont, Incorporated, USA, (1996).

Eakin v Continental Illinois National Bank \& Trust Co. (1989) 875 F.2d 114 .116. Edward Owen Engineering Ltd v Barclays Bank International Ltd. [1978] 1 Lloyd's Rep. 166

Enonchong N, 'the Autonomy Principle of Letters of Credit: An Illegality Exception?' Lloyd's Maritime and Commercial Law Quarterly,(2006), 404

Enonchong.N, 'The Independence Principle of Letters of Credits and Demand Guarantees'. Oxford University Press, (2011). 9

Ellinger .P, Noe. D, the Law and Practice of Documentary Letters of Credit, Hart, (2010), 141

Ellinger, E. P. "Documentary Credits and Fraudulent Documents." Current Problems Of International Trade Financing. Singapore: Malaya Law Review and 
Butterworth \& Co 185 (1983).

Xiang, Gao, and Ross P. Buckley. "Comparative Analysis of the Standard of Fraud Required under the Fraud Rule in Letter of Credit Law, A." Duke J. Comp. \& Int'l L. 13 (2003): 293.

Gao, Xiang. "The Fraud Rule in the Law of Letters of Credit." (2002).

García, Roberto Luis Frías. “The Autonomy Principle of Letters of Credit.” Mexican Law Review 3, no. 1 (2010): 4.

Gordley, James. "Comparative Legal Research: Its Function in the Development of Harmonized Law." The American Journal of Comparative Law 43, no. 4 (1995): 555-567.

Hamzeh Malas \& Sons v. British Imex Industries Ltd [1958] 2 QB 127; [1958] 2 WLR 100; [1958] 1 All ER 262, C.A.

Harbottle (RD) (Mercantile) Ltd v National Westminster Bank Ltd [1978] 1 QB 146.

Harfield.H, Bank Credits and Acceptances (5th ed.), New York, (1974),

Kelly-Louw, Michelle. "Documentary Nature of Demand Guarantees and the Doctrine of Strict Compliance (Part 1), The." S. Afr. Mercantile LJ 21 (2009): 306.

Lu, Lu. "The Exceptions in Documentary Credits in English Law." (2011). 75

Malek, Ali, and David Quest. “Jack: Documentary Credits." (2009).

Official Comment to Article 5 of the Uniform Commercial Code, para. 2

Power Curber International Ltd v. National Bank of Kuwait SAK [1981]2 Lloyd's Rep 394.

Schmitthoff's Export Trade - The Law and Practice of International Trade (12th ed.)Sweet \& Maxwell, (2012),

Semetex Corporation v UBAF Arab American Bank [1995] 2Bank LR 73

Sztejn v Henry Schroder Banking Corporation 31 NYS 2d 631 (1941)

ThemehelpLtd. v. West, (1995) 4 All E.R. 215

Tóth, Zsuzsanna. "DOCUMENTARY CREDITS IN INTERNATIONAL COMMERCIAL TRANSACTIONS WITH SPECIAL FOCUS ON THE FRAUD RULE.,,(2006)

Trade Finance Fraud -Understanding the Threats and reducing the Risk, A Special Report prepared by the ICC International Maritime Bureau (Paris) ,(2002), 9 Trans Trust SPRL v Danubian Co Ltd [1952] 2QB 297 at 304

Uniform Customs and Ptactice for Dcoumentary Letters of Credit . ICC ,( 2007). United City Cooperation v. Allied Arab Bank (1985) 2 Lloyds Rep .554, 561

United City Merchants (Investment) Limited $v$ Royal Bank of Canada [1982] 2 All E.R. 725

United City Merchants (Investment) Limited v Royal Bank of Canada [1979] 1 Lloyd's Law Reports 267

United City Merchants (Investments) Ltd v Royal Bank Of Canada [1983] 1AC 168,183

United Trading Corporation SA and Murray Clayton Ltd $v$ allied Arab Bank Ltd 
ICLR, 2015, Vol. 15, No. 2.

[1985] 2 Lloyd's Law Reports 554 (CA)

Ward Petroleum Corp. v Federal Deposit Ins. Corp. (1990) 903 F.2d 1299.

White and Co Inc vs Chamet Handel Training (S) Pte Ltd (1993) 1 SLR 65

Zhang, Yanan. Approaches to Resolving the International Documentary Letters of

Credit Fraud Issue. University of Eastern Finland, (2011). 